\title{
The role of high-fat diets and physical activity in the regulation of body weight
}

\author{
Patrick Schrauwen* and Klaas R. Westerterp \\ Department of Human Biology, Maastricht University, P.O. Box 616, 6200 MD Maastricht, The Netherlands
}

(Received 11 August 1999 - Revised 7 January 2000 - Accepted 22 January 2000)

\begin{abstract}
The prevalence of obesity is increasing in westernized societies. In the USA the age-adjusted prevalence of $\mathrm{BMI}>30 \mathrm{~kg} / \mathrm{m}^{2}$ increased between 1960 and 1994 from $13 \%$ to $23 \%$ for people over 20 years of age. This increase in the prevalence of obesity has been attributed to an increased fat intake and a decreased physical activity. However, the role of the impact of the level of dietary fat intake on human obesity has been challenged. High-fat diets, due to their high energy density, stimulate voluntary energy intake. An increased fat intake does not stimulate its own oxidation but the fat is stored in the human body. When diet composition is isoenergetically switched from low to high fat, fat oxidation only slowly increases, resulting in positive fat balances on the short term. Together with a diminished fat oxidation capacity in pre-obese subjects, high-fat diets can therefore be considered to be fattening. Another environmental factor which could explain the increasing prevalence of obesity is a decrease in physical activity. The percentage of body fat is negatively associated with physical activity and exercise has pronounced effects on energy expenditure and substrate oxidation. High-intensity exercise, due to a lowering of glycogen stores, can lead to a rapid increase in fat oxidation, which could compensate for the consumption of high-fat diets in westernized societies. Although the consumption of high-fat diets and low physical activity will easily lead to the development of obesity, there is still considerable inter-individual variability in body composition in individuals on similar diets. This can be attributed to the genetic background, and some candidate genes have been discovered recently. Both leptin and uncoupling protein have been suggested to play a role in the prevention of diet-induced obesity. Indeed, leptin levels are increased on a high-fat diet but this effect can be attributed to the increased fat mass observed on the high-fat diet. No effect of a high-fat diet per se on leptin levels is observed. Uncoupling proteins are increased by high-fat diets in rats but no data are available in human subjects yet. In conclusion, the increased intake of dietary fat and a decreasing physical activity level are the most important environmental factors explaining the increased prevalence of obesity in westernized societies.
\end{abstract}

High-fat diet: Physical activity: Obesity: Fat oxidation

Obesity is becoming a major health problem in affluent societies. The incidence of obesity is increasing rapidly. In the USA the age-adjusted prevalence of BMI $>30 \mathrm{~kg} / \mathrm{m}^{2}$ increased between 1960 and 1994 from $13 \%$ to $23 \%$ for people over 20 years of age. The overall prevalence of BMI $>25 \mathrm{~kg} / \mathrm{m}^{2}$ was found to be $55 \%$ (Flegal et al. 1998). In Europe, the most comprehensive data on the prevalence of obesity (BMI $>30 \mathrm{~kg} / \mathrm{m}^{2}$ ) comes from the World Health Organization MONICA study (Keil \& Kuulasmaa, 1989). This study, for which data was collected between 1983 and 1986, shows that in only three out of thirty-eight participating centres was the prevalence of obesity below
$10 \%$. In most European countries this prevalence is still rising (Seidell, 1995). In Australia, Canada and Brazil an increase in the prevalence of obesity has also been reported (Millar \& Stephens, 1993; Boyle et al. 1994; Monteiro et al. 1995) and even the prevalence of obesity in developing countries (although still below $5 \%$ ) is increasing (Seidell $\&$ Rissanen, 1997). From these figures it can thus be concluded that the prevalence of obesity is increasing worldwide. The increase in the prevalence of obesity is often ascribed to the changing lifestyle in westernized societies, among which is the consumption of high-fat diets. In the last 20 years many food products have become

\footnotetext{
Abbreviation: FQ, food quotient.

* Corresponding author: Dr Patrick Schrauwen, fax + 3143 3670976, email p.schrauwen@hb.unimaas.nl
} 
available that are cheap, palatable and high in fat content, and thus, dietary fat intake has increased rapidly. Since dietary fat is the most energy-dense macronutrient, with about $38 \mathrm{~kJ} / \mathrm{g}$ (in comparison, carbohydrate and protein only provide about $17 \mathrm{~kJ} / \mathrm{g}$ ), an increase in dietary fat intake can easily promote an increase in energy intake and thus result in overconsumption. Epidemiological evidence for a relationship between fat intake and obesity comes from Lissner \& Heitmann (1995), who reviewed data from thirteen studies examining the relationship between fat intake and obesity. In eleven out of thirteen studies a statistically significant relationship was found between energy-adjusted fat intake and one or more measures of obesity. Other evidence for a role of dietary fat intake in the increasing prevalence of obesity comes from studies examining the concurrent changes in obesity and fat intake over extended periods of time. For example, Sonne-Holm \& Sorensen (1977) showed that the increase in obesity between 1945 and 1975 in Danish men was parallelled by an increase in fat intake. Together with the finding that the capacity of the human body to respond to an increased fat intake with an increased fat oxidation is limited (Blaak et al. 1994), and high-fat diets thus would preferentially lead to deposition of dietary fat into the fat stores, these results indicate that the consumption of high-fat diets seems to be a reasonable explanation for the increased prevalence of obesity in westernized societies. Recently, however, the impact of the level of dietary fat intake on human obesity has been challenged (Katan et al. 1997). The prevalence of obesity in the USA is still increasing, whereas the intake of fat is decreasing (Kuczmarski et al. 1994). Therefore, a decrease in physical activity has been proposed to be responsible for the increasing prevalence of obesity in westernized societies. Occupational work has been automated and this is not compensated for by an increase in physical activity during leisure time. Therefore, energy expenditure will be lower and thus a positive energy balance is likely to occur, even when energy intake does not change. A decreased physical activity might also therefore be responsible for the increased prevalence of obesity. In most data sets from the general US population, negative relationships between measures of physical activity (self-reports) and indices of obesity have been reported (Eck et al. 1992; Kuczmarski et al. 1994). However, accurate population-based records of trends in physical activity over time are lacking, which can be explained by difficulties in measuring physical activity in large populations.

Finally, in our westernized society there is still large individual variability in body weight even in people on similar diets. Thus, there seems to be an important interaction between dietary factors and genetic background. Indeed, adoption and twin studies show the impact of the interaction between environmental and genetic factors on body composition (Stunkard et al. 1986).

In this review, evidence will be presented for a role of high-fat diets in the development of obesity. The effects of high-fat diets on fat intake and fat oxidation will also be discussed. Furthermore, some evidence will be given for an interaction between high-fat diets and recently discovered, genetic determinants of obesity.

\section{The effect of high-fat diets on energy intake}

The development of obesity is characterized by an imbalance (temporal) between energy intake and energy expenditure. An increased energy intake, when not accompanied by an increased energy expenditure, will result in a positive energy balance and an increase in body weight. Since high-fat diets are characterized by a high energy density and high palatability they are often considered to increase energy intake (Miller et al. 1990; Prewitt et al. 1991; Klesges et al. 1992; Verboeket-van de Venne et al. 1996). In the Leeds (W. Yorks., UK) high-fat study there were nineteen times more obese subjects among the consumers of a habitual diet with a high fat content (>45\% of energy derived from fat) than among the consumers of a habitual diet with a low fat content $(<35 \%$ of energy derived from fat) (Blundell \& Macdiarmid, 1997). Furthermore, numerous studies show that voluntary energy intake is higher on a high-fat diet (Lissner et al. 1987; Blundell et al. 1993; Lissner \& Heitmann, 1995; Westerterp et al. 1996b). It has even been suggested that high-fat diets are more fattening than isoenergetic low-fat diets, i.e. independent of an effect on energy intake (Romieu et al. 1988; Miller et al. 1990). However, recent data clearly illustrate that the fat content of the diet influences body fat only when energy intake is also increased (Westerterp et al. 1996b). One explanation for the increased energy intake on high-fat diets is the higher palatability of high-fat diets compared with low-fat diets, stimulating voluntary food consumption. Another explanation for the increased energy intake on high-fat diets is that in commercially available food items, the percentage of energy derived from fat is highly correlated with energy density (Poppitt, 1995; Westerterp-Plantenga et al. 1996). Thus, when a similar volume of food is consumed, energy intake will be higher on high-fat diets compared with lowfat diets. It has therefore been suggested that it is simply the energy density of the diet instead of the dietary fat content that promotes over-consumption. Evidence for this is provided by Saltzman et al. (1997), who found no difference in voluntary energy intake between low-fat (20\% of energy derived from fat) and high-fat (40\% of energy derived from fat) diets when matched for energy density and palatability. This finding indicates that dietary advice to prevent the development of obesity should focus on a reduction of the consumption of energy-dense food items. However, although low-fat food items can also have a high energy density, in practice the fat content is the major determinant of energy density and the consumption of high-fat diets will therefore favour over-consumption, possibly leading to obesity.

\section{The effect of dietary fat on fat oxidation}

\section{J. P. Flatt's two compartment model}

As stated earlier, weight maintenance requires that, in the long term, energy intake is equal to energy expenditure. However, this also requires a close match between intake and oxidation for the separate macronutrients. Important work on this concept was done by Flatt $(1987 a, b, 1988)$. He described the features of body-weight maintenance with a 


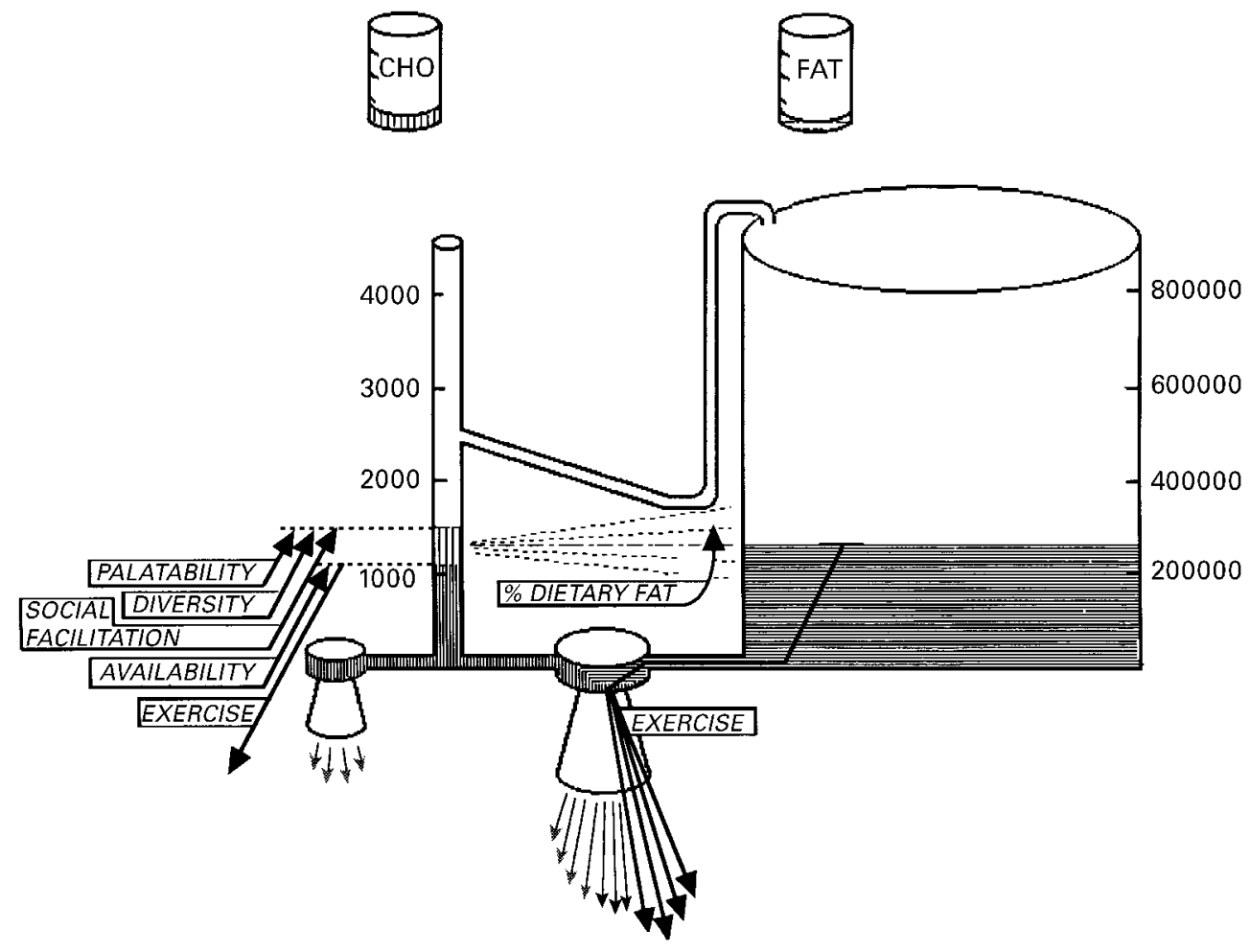

Fig. 1. Two-compartment model of J. P. Flatt, illustrating the effect of circumstantial and lifestyle factors on adiposity. The small and the large reservoirs represent the human body's limited capacity for storing glycogen and its large capacity for storing fat respectively (expressed as kcal; $1 \mathrm{kcal} 4.184 \mathrm{~kJ}$ ). The small turbine illustrates the exclusive use of glucose by the brain. The relative proportions of glucose and fatty acids used by the large turbine are assumed to be influenced by the levels to which the two reservoirs are filled at a given time. Reproduced, with permission, from Flatt (1987a).

two-compartment model (Flatt, 1987a; Fig. 1). The small reservoir is representative for the carbohydrate stores in the human body, which can vary between 200 and $800 \mathrm{~g}$ glycogen. The large reservoir represents the capacity of the human body to store fat, which is huge when compared with the glycogen stores. The relative size of the two reservoirs determines the composition of the fuel being oxidized. Expansion of one reservoir will lead to an increased influx from this reservoir and a greater contribution to the fuel mix oxidized. Addition of a fixed quantity (carbohydrates) to the small reservoir will lead to an increase in the contribution of carbohydrates to the fuel mix oxidized (rise in RER), whereas addition of an isoenergetic quantity (fat) to the large reservoir will only result in minor changes in the fuel-mix oxidized. Furthermore, the model predicts that one of the driving forces for food intake is a physiological requirement to maintain glycogen stores at a certain level. With this model, the effect of the fat content of the diet on substrate metabolism can be predicted. Addition of a fat supplement to the diet will not stimulate fat oxidation and, in the long term, fat mass will increase. When diet composition is isoenergetically switched from low-fat to high-fat, the model predicts that an expansion of the large reservoir (fat mass) or a decrease in the small reservoir (glycogen stores) is required to allow an increase in fat oxidation. Since, according to the model, man will voluntarily eat to maintain glycogen stores, a higher amount of energy will be ingested when dietary composition is high in fat (and thus low in carbohydrate). Therefore, consumption of high-fat diets will lead to a positive fat balance and thus an increase in fat mass will occur. This increase in the fat mass is then accompanied by increased fat oxidation, thereby compensating for the high fat intake on the high-fat diet. Thus, the model gives a possible explanation for the suggested link between dietary fat and obesity observed in western society. With the model it can be explained that physical activity might prevent the development of obesity when high-fat diets are consumed, by lowering glycogen stores and thus increasing fat oxidation. Since physical activity seems to influence food preferences, with active subjects consuming carbohydraterich diets (Westerterp et al. 1996a), and exercise results in a short-term reduction of energy intake (Westerterp-Plantenga et al. 1997), lowering of the glycogen stores by physical activity does not necessarily lead to a drive to increase food intake. Therefore, the model predicts an overall positive effect of intensive (i.e. glycogen lowering) physical activity on the development of obesity.

Apart from the theoretical explanation for the effect of high-fat diets on body-weight regulation given by the twocompartment model, several studies have examined the effect of fat content of the diet on substrate oxidation. In these studies, two approaches have been used: the effect of fat supplements in excess of energy requirements, or the effect of isoenergetic high- and low-fat diets, supplied in energy balance. 
Table 1. The effect of fat supplements on fat oxidation

\begin{tabular}{|c|c|c|c|c|c|c|c|c|c|}
\hline \multirow[b]{2}{*}{ Study } & \multirow[b]{2}{*}{ Subjects } & \multirow[b]{2}{*}{$n$} & \multirow{2}{*}{$\begin{array}{c}\text { Fat in diet } \\
(\%)\end{array}$} & \multirow{2}{*}{$\begin{array}{c}\text { Size of fat } \\
\text { supplement }(g)\end{array}$} & \multirow{2}{*}{$\begin{array}{l}\text { Duration of diet } \\
\text { (h) }\end{array}$} & \multicolumn{2}{|c|}{ Fat oxidation $(\mathrm{g} / \mathrm{h})$} & \multicolumn{2}{|c|}{ Fat balance $(\mathrm{g})$} \\
\hline & & & & & & Mean & SD & Mean & SD \\
\hline \multirow[t]{2}{*}{ Flatt et al. (1985) } & Lean & 7 & 11 & & 9 & $4 \cdot 2$ & $1 \cdot 6$ & -32 & 18 \\
\hline & & & 50 & 50 & 9 & $4 \cdot 6$ & 1.6 & +7 & 10 \\
\hline \multirow{2}{*}{ Schutz et al. (1989) } & Lean & 7 & 35 & & 24 & $6 \cdot 3$ & & -43 & \\
\hline & & & 52 & 106 & 24 & $6 \cdot 0$ & & +75 & \\
\hline \multirow[t]{2}{*}{ Bennett et al. (1992) } & Lean & 8 & 30 & & 18 & 3.9 & $1 \cdot 8$ & +34 & 26 \\
\hline & & & 37 & 50 & 18 & 4.0 & $2 \cdot 0$ & +72 & 24 \\
\hline \multirow[t]{2}{*}{ Dallosso \& James (1984) } & Lean & 8 & 30 & & $7 \times 24$ & & & +14 & 25 \\
\hline & & & 50 & 135 & $7 \times 24$ & & & +163 & 27 \\
\hline \multirow[t]{4}{*}{ Thomas et al. (1992) } & Lean & 11 & 37 & & $7 \times 24$ & 4.4 & & & \\
\hline & & & 52 & 56 & $7 \times 24$ & $4 \cdot 8$ & & & \\
\hline & Obese* & 10 & 38 & & $7 \times 24$ & $5 \cdot 3$ & & & \\
\hline & & & 52 & 59 & $7 \times 24$ & $6 \cdot 2$ & & & \\
\hline
\end{tabular}

* NA, not available.

Obesity was defined as a BMI $>30 \mathrm{~kg} / \mathrm{m}^{2}$.

\section{The effect of fat supplements on fat oxidation}

Flatt et al. (1985) investigated the effect of dietary fat on postprandial substrate utilization and nutrient balance in seven young men, $1 \mathrm{~h}$ before and $9 \mathrm{~h}$ after the ingestion of two different breakfasts. Subjects were given a low-fat breakfast (11\% of energy derived from fat) or a low-fat breakfast with a $50 \mathrm{~g}$ fat supplement. As predicted by his model, substrate oxidation was not influenced by the surplus fat. After the low-fat breakfast ( $9 \mathrm{~h}$ ) fat balance was negative, whereas after the fat supplement a positive fat balance was reached. Similar results were obtained by Bennett et al. (1992). Adding $50 \mathrm{~g}$ fat to a standard breakfast did not increase fat oxidation during an $18 \mathrm{~h}$ period following the breakfast and therefore it was concluded that all surplus fat was stored. Schutz et al. (1989) studied the effect of a dietary fat surplus on substrate oxidation in a respiration chamber over $60 \mathrm{~h}$ intervals. After a $12 \mathrm{~h}$ run-in period, subjects consumed a mixed diet (35\% of energy derived from fat) in the first $24 \mathrm{~h}$ and were in energy and fat balance. Adding $106 \mathrm{~g}$ fat to the diet in the next $24 \mathrm{~h}$ did not change energy expenditure or substrate oxidation, leading to the conclusion that the total fat surplus was stored. Fat balance and energy balance were closely correlated. The effect of 1 week fat-overfeeding on $24 \mathrm{~h}$ substrate oxidation was studied by Dallosso \& James (1984). They found that the fat overfeeding had no effect on fat oxidation and the surplus fat (50\% of normal energy intake) was stored. To study the influence of diet composition on the regulation of body weight, Thomas et al. (1992) fed eleven lean and ten obese subjects (body fat $>25 \%$ for men and $>30 \%$ for women) ad libitum with low-fat and high-fat diets for 1 week. On day 7 on each diet, $24 \mathrm{~h}$ substrate oxidation was measured using a respiration chamber. Voluntary energy intake was higher on the high-fat diet compared with the low-fat diet. On day 7 of the low-fat diet, carbohydrate intake was positively related to carbohydrate oxidation, indicating that carbohydrate intake stimulated its own oxidation, and carbohydrate balance was reached. After $7 \mathrm{~d}$ on the high-fat diet, fat intake was related to fat oxidation, but only in the lean subjects. Furthermore, even the lean subjects were not able to stimulate fat oxidation to an extent sufficient to match fat intake, and a positive fat balance was reached.

The results of these studies (Table 1) clearly show that, both in the short as well as in the long term, fat intake does not stimulate its own oxidation, when dietary fat is given in excess of energy requirements. The excess dietary fat is stored in the adipose tissue and energy balance is closely correlated with fat balance. However, the question remains whether similar effect would be observed if subjects were not overfed by adding fat to the diet, but by adding carbohydrates. To test this, Horton et al. (1995) overfed isoenergetic amounts (50\% above energy requirements) of fat and carbohydrate (for $14 \mathrm{~d}$ each) to lean and obese men. It was found that $14 \mathrm{~d}$ carbohydrate overfeeding produced a rapid increase in carbohydrate oxidation (2-fold), whereas $14 \mathrm{~d}$ fat overfeeding had no effect on fat oxidation at all. Furthermore, during carbohydrate overfeeding more of the excess energy was oxidized and less stored in the body when compared with fat overfeeding. As a result, positive fat balance was much more pronounced after carbohydrate overfeeding compared with fat overfeeding.

These results thus illustrate that an excess fat intake does not stimulate its own oxidation and therefore promotes the development of a positive fat balance and thus obesity.

\section{The effect of isoenergetic high-and low-fat diets on fat oxidation}

Another approach for studying the effect of diet composition on substrate metabolism is the comparison of isoenergetic high- and low-fat diets with energy contents equal to the individuals' energy requirements. In these studies RER is compared with food quotient (FQ). The RER is the ratio of $\mathrm{CO}_{2}$ produced to $\mathrm{O}_{2}$ consumed by the body $\left(\mathrm{VCO}_{2}: \mathrm{VO}_{2}\right)$. Since the amount of $\mathrm{CO}_{2}$ produced and $\mathrm{O}_{2}$ consumed is dependent on the substrate metabolized, RER is used to measure substrate oxidation. In case of carbohydrate-only oxidation, RER is equal to $1 \cdot 0$, whereas with fat-only oxidation, RER equals $0 \cdot 7$. The FQ is the theoretical RER when all dietary carbohydrates, fat and protein would be completely oxidized.

Abbott et al. (1990) studied the acute effect of such 
high-fat (65\% of energy derived from fat) and low-fat (20\% of energy derived from fat) diets on $24 \mathrm{~h}$ substrate oxidation in Pima Indians. On the high-fat diet, $24 \mathrm{~h}$ RER was similar to FQ whereas on the low-fat diet RER was significantly less than FQ. McNeill et al. (1988) studied the long-term effects ( $6 \mathrm{~d}$ ) of diet composition on fasting RER in eleven healthy women. Fasting RER was lower after a diet with normal composition (41\% of energy derived from fat) compared with a high-carbohydrate diet (31\% of energy derived from fat) and the difference in RER was similar to the difference in FQ between the diets. Similarly, Hurni et al. (1982) studied the long-term (7 d) effects of low-fat (4\% of energy derived from fat) and medium-fat (37\% of energy derived from fat) diets on substrate metabolism in lean subjects. RER ( $24 \mathrm{~h})$ was lower on the low-fat diet compared with the high-fat diet. Hill et al. (1991) studied lean subjects after 3 and $7 \mathrm{~d}$ on high-fat (60\% of energy derived from fat) and low-fat (20\% of energy derived from fat) diets. On day 3, RER was shifted in the direction of FQ on both diets, and no further changes in RER between day 3 and day 7 were observed.

Several studies were performed to study the effect of diet composition on substrate metabolism in groups with different susceptibility to obesity. Lean \& James (1988) studied the acute effect of isoenergetic low-fat (3\% of energy derived from fat) diet and high-fat (40\% of energy derived from fat) diets on $24 \mathrm{~h}$ substrate oxidation in lean, obese (BMI $>32 \mathrm{~kg} / \mathrm{m}^{2}$ ) and 'post-obese' (previously obese with $\mathrm{BMI}>32 \mathrm{~kg} / \mathrm{m}^{2}$, and at least 6 months weight-stable with BMI $<25 \mathrm{~kg} / \mathrm{m}^{2)}$ women. The lean and obese women responded to the high-fat diet by increasing fat oxidation, whereas in the post-obese women the increase in fat oxidation in response to the high-fat diet was blunted. This might indicate a diminished capacity for fat oxidation in post-obese (and predisposed) subjects. Similar results were obtained by Astrup et al. (1994). They studied whether subjects with a predisposition to obesity (post-obese) respond differently to changes in dietary composition compared with controls. Subjects consumed a low-fat (20\% of energy derived from fat) or high-fat $(50 \%$ of energy derived from fat) diet for $3 \mathrm{~d}$ at home and subsequently for $24 \mathrm{~h}$ in a respiration chamber. In the lean subjects the high-fat diet stimulated fat oxidation and substrate balance was reached. However, the post-obese subjects were not able to stimulate their fat oxidation sufficiently to match fat intake. Verboeket-van de Venne et al. (1994) studied the effect of $3 \mathrm{~d}$ low-fat $(10 \%$ of energy derived from fat), medium-fat (30\% of energy derived from fat) or high-fat ( $50 \%$ of energy derived from fat) diets on $24 \mathrm{~h}$ substrate oxidation in restrained and unrestrained eaters. On the low-fat and medium-fat diets RER was lower than FQ, whereas on the high-fat diet RER was equal to FQ. However, the restrained eaters, who are considered to have higher susceptibility to becoming obese, responded with a smaller increase in fat oxidation on the high-fat diet than the unrestrained eaters.

The studies reported earlier indicate that isoenergetic low- or high-fat diets influence substrate oxidation, with RER shifting in the direction of FQ. Moreover, some of the studies mentioned earlier indicate that RER is lower than FQ on a low-fat diet, which is in contrast with the notion that carbohydrate intake rapidly stimulates carbohydrate oxidation. However, this can be explained by the fact that many of the studies on the effect of isoenergetic high- and low-fat diets on fat oxidation have difficulties in achieving energy balance and the results are confounded by energy imbalance. While in the respiration chamber, energy requirements are often based on (a percentage of) energy intake measured on a 'weight-maintenance diet' or on predicted (or measured) resting metabolic rate multiplied by a factor for physical activity inside the chamber. We recently showed that the day-to-day variance in energy expenditure in a respiration chamber, especially when the level of activity is controlled for, is limited (Schrauwen et al. 1997c). Therefore, when energy expenditure is measured on $1 \mathrm{~d}$, energy intake can be adjusted to energy requirements and subjects can be fed in energy balance. We used this approach to study the effect of diet composition on substrate oxidation when subjects were shifted from a low-fat diet (30\% of energy derived from fat) to a high-fat diet (60\% of energy derived from fat), while staying in the respiration chamber for $7 \mathrm{~d}$. Subjects showed a close balance between energy expenditure and energy intake and FQ was equal to RER after $2 \mathrm{~d}$ on the low-fat diet. On the high-fat diet we found that RER shifted in the direction of FQ but that only after $7 \mathrm{~d}$ was RER equal to FQ (Schrauwen et al. 1997a).

Taken together, the results from these studies (Table 2) indicate that isoenergetic high- and low-fat diets influence substrate oxidation, with RER shifting in the direction of FQ. However, the adjustment of RER to FQ on a high-fat diet is slow and requires several days. Thus day-to-day variability in dietary fat intake is not accompanied by rapid changes in fat oxidation and therefore positive fat balance will occur. It might be that these cumulative positive fat balances will, over time, lead to the development of obesity. Furthermore the results suggest that a diminished fat oxidation capacity might be a predictor for the development of obesity.

The results discussed earlier strongly suggest an important role for the dietary fat content in the development of obesity. However, a decreased physical activity has also been proposed to be responsible for the increasing prevalence of obesity (Saris, 1996).

\section{Physical activity as a determinant of energy and substrate metabolism}

The development of obesity is, by definition, characterized by an energy intake exceeding energy expenditure. Therefore, it seems logical that physical activity could prevent the development of obesity. However, studies examining the effect of physical activity on obesity are scarce, due to methodological problems in quantifying the amount of physical activity. The doubly-labelled water method allows the measurement of average daily metabolic rate, i.e. the total of energy expended during $24 \mathrm{~h}$. If this measurement is combined with the measurement of BMR, energy expenditure for physical activity can be calculated from the difference between BMR and average daily metabolic rate. With this method, it was shown that energy expended during physical activity is negatively correlated with body 
Table 2. Food quotient (FQ) and RER in isoenergetic high- and low-fat diets

\begin{tabular}{|c|c|c|c|c|c|c|c|c|}
\hline \multirow[b]{2}{*}{ Study } & \multirow[b]{2}{*}{ Subjects } & \multirow[b]{2}{*}{$n$} & \multirow{2}{*}{$\begin{array}{l}\text { Fat in diet } \\
(\%)\end{array}$} & \multirow{2}{*}{$\begin{array}{l}\text { Duration of diet } \\
\text { (d) }\end{array}$} & \multirow[b]{2}{*}{$\mathrm{FQ}$} & \multicolumn{2}{|c|}{ RER } & \multirow[b]{2}{*}{$\mathrm{RER}-\mathrm{FQ}$} \\
\hline & & & & & & Mean & SD & \\
\hline \multirow{2}{*}{ McNeill et al. (1988) } & Lean and obese* & 6 and 5 & 31 & 6 & 0.88 & 0.85 & 0.03 & -0.03 \\
\hline & & & 41 & 6 & 0.85 & 0.82 & 0.03 & -0.03 \\
\hline \multirow[t]{2}{*}{ Abbott et al. (1990) } & Pima Indians & 20 & 20 & 1 & 0.91 & 0.88 & 0.01 & -0.03 \\
\hline & & & 42 & 1 & 0.83 & 0.84 & 0.01 & 0.01 \\
\hline \multirow[t]{2}{*}{ Hurni et al. (1982) } & Lean & 11 & 4 & 7 & 0.95 & 0.88 & 0.01 & -0.07 \\
\hline & & & 37 & 7 & 0.85 & 0.80 & 0.01 & -0.05 \\
\hline \multirow[t]{2}{*}{ Hill et al. (1991) } & Lean & 8 & 20 & 7 & 0.92 & 0.86 & 0.01 & -0.06 \\
\hline & & & 60 & 7 & 0.77 & 0.75 & 0.01 & -0.02 \\
\hline \multirow[t]{6}{*}{ Lean \& James (1988) } & Lean & 6 & 3 & 1 & 0.96 & 0.87 & 0.01 & -0.09 \\
\hline & & & 40 & 1 & 0.85 & 0.82 & 0.01 & -0.03 \\
\hline & Obese* $^{*}$ & 10 & 3 & 1 & 0.96 & 0.87 & 0.01 & -0.09 \\
\hline & & & 40 & 1 & 0.85 & 0.82 & 0.01 & -0.03 \\
\hline & Post-obese† & 7 & 3 & 1 & 0.96 & 0.89 & 0.01 & -0.07 \\
\hline & & & 40 & 1 & 0.85 & 0.85 & 0.01 & 0.00 \\
\hline \multirow[t]{2}{*}{ Schrauwen et al. (1997a) } & Lean & 12 & 30 & 2 & 0.88 & 0.88 & 0.01 & 0.00 \\
\hline & & & 60 & 7 & 0.80 & 0.80 & 0.01 & 0.00 \\
\hline \multirow{4}{*}{$\begin{array}{l}\text { Verboeket-van de Venne et al. } \\
\text { (1994) }\end{array}$} & Unrestrained & 7 & 10 & 3 & 0.94 & 0.90 & 0.01 & -0.04 \\
\hline & & & 50 & 3 & 0.82 & 0.82 & 0.00 & 0.00 \\
\hline & Restrained $\ddagger$ & 7 & 10 & 3 & 0.94 & 0.91 & 0.00 & -0.03 \\
\hline & & & 50 & 3 & 0.82 & 0.83 & 0.00 & 0.01 \\
\hline
\end{tabular}

$\mathrm{FQ}$, food quotient.

* Obesity was defined as a BMl $>30 \mathrm{~kg} / \mathrm{m}^{2}$.

† Post-obesity was defined as previously obese with BMI $>32 \mathrm{~kg} / \mathrm{m}^{2}$, and at least 6 months weight-stable with BMl $<25 \mathrm{~kg} / \mathrm{m}^{2}$.

$\ddagger$ Restrained eating was defined as a score $>15$ on the Herman-Polivy restraint scale.

fat percentage in males (Westerterp \& Goran, 1997). Schulz \& Schoeller (1994) combined data from a large number of doubly-labelled water studies and found a negative correlation between body fat percentage, both in males and females. Furthermore, training studies showed that after a 40-week training programme previously untrained subjects had an increase in fat-free mass and decrease in fat mass (Westerterp et al. 1994). These studies suggest a positive effect of physical activity in the prevention of obesity due to an elevation of daily energy expenditure. Apart from the elevation in energy expenditure during physical activity, it has been suggested that physical activity also increases resting energy needs. One of the most important determinants of resting metabolic rate is the fat-free mass (Ravussin et al. 1986) and endurance training increases the latter. Whether endurance training influences resting metabolic rate after adjustment for body composition is still controversial. Some studies have shown an increase in resting metabolic rate, adjusted for fat-free mass and fat mass, in response to training (Tremblay et al. 1986; Poehlman et al. 1988), whereas others did not (Davis et al. 1983; Schulz et al. 1991; Westerterp et al. 1994). However, there is agreement that in the short term, energy expenditure is elevated above resting metabolic rate for several hours following exercise, a phenomenon called excess post-exercise $\mathrm{O}_{2}$ consumption. Interestingly, the type of physical activity could have an influence on the amount of excess post-exercise $\mathrm{O}_{2}$ consumption. Some studies have shown that high-intensity exercise has a more pronounced effect on post-exercise energy expenditure compared with low-intensity exercise (Gore \& Whither, 1990; Smith \& Naughton, 1993; Phelain et al. 1997), whereas others found no difference (Sedlock et al. 1989; Sedlock, 1991). Treuth et al. (1996) showed that average daily metabolic rate was elevated by $0.6 \mathrm{MJ} / \mathrm{d}$ after a $60 \mathrm{~min}$ high-intensity interval exercise session compared with an equal amount of work performed in a 60 min low-intensity exercise session.

These results suggest that physical activity might be helpful in the prevention of obesity by elevating average daily metabolic rate. However, this does not mean that a decreased physical activity is the sole reason for the increasing prevalence of obesity in westernized societies. In a recent review it was illustrated that obese subjects were not less physically active when compared with normalweight subjects (Westerterp, 1999).

Beyond the effects of physical activity on energy metabolism, physical activity has been used as a tool to promote fat oxidation. It is well known that at low exercise intensities fat oxidation is responsible for the major part of the energy demands and that with increasing exercise intensity the contribution of carbohydrate oxidation increases. It has been shown that maximal fat oxidation is achieved between 40 and $65 \%$ of maximal power output $\left(\mathrm{W}_{\max }\right)$ (Romijn et al. 1993). Therefore, for a long time low-intensity exercise has been considered the most beneficial for the treatment of obesity. However, highintensity exercise has been suggested to have a more pronounced impact on post-exercise fat oxidation (Tremblay et al. 1994) and low glycogen levels could be involved in the high post-exercise fat oxidation. According to the model of Flatt $(1987 a, b, 1988)$, fat oxidation can be raised to match fat intake on a high-fat diet by maintaining lower glycogen levels. As discussed earlier, the consumption of a high-fat diet, while in energy balance, leads to a gradual increase in fat oxidation. One explanation for the latter is that declining glycogen stores, indicated by a negative carbohydrate balance (as RER $>\mathrm{FQ}$ ) on the first days of a 
high-fat diet, are responsible for the gradual increase in fat oxidation. Therefore, the hypothesis was tested that acute lowering of the glycogen stores, by high-intensity exercise, would lead to a rapid increase in fat oxidation. It was found that lean and obese subjects were capable of adjusting fat oxidation to equal fat intake within $1 \mathrm{~d}$ when glycogen stores were low (Schrauwen et al. 1997b, 1998). Since most people do not consume high-fat diets for several days in a row but have a large day-to-day fluctuation in fat intake, most people will not adjust their fat oxidation to their fat intake and cumulative positive fat balances might occur. Therefore, lowering of the glycogen stores (by highintensity exercise) might prevent cumulative positive fat balances, and thus eventually the development of obesity. Therefore, (high-intensity) exercise can counterbalance the increasing intake of fat in our westernized societies and might prevent the development of obesity.

Apart from the effect of physical activity on energy and substrate metabolism, regular physical activity might have an effect on food intake preferences. Subjects with a higher spontaneous activity level consumed more carbohydrate (Westerterp et al. 1996a), and exercise resulted in a shortterm reduction in hunger and energy intake (WesterterpPlantenga et al. 1997).

Together these results suggest that regular physical activity might be an important strategy in the prevention of diet-induced obesity. Apart from an effect on energy intake, high-intensity physical activity, leading to lowering of the glycogen stores, might be a good strategy for obese people to enhance their fat metabolism. The combination of (highintensity) exercise and a low-fat diet might be a helpful tool in the treatment of obesity. However, obese subjects are not less active compared with normal-weight subjects and thus decreased physical activity can not be the sole explanation for the increasing prevalence of obesity in our westernized societies.

\section{Mechanisms behind the effect of high-fat diets on fat oxidation}

As discussed earlier, an increased dietary fat content does not stimulate its own oxidation. However, it is not clear why the adaptation of fat oxidation to fat intake is slow. To examine this, whole-body fat oxidation should be studied in more detail and be divided into the oxidation of fat derived from plasma, intramuscular triacylglycerol or VLDLtriacylglycerol. Using labelled fatty acids, plasma-derived fatty acid oxidation can be distinguished from the oxidation of intramuscular triacylglycerol-VLDL-triacylglycerol. We used this approach to study the effect of a high-fat diet (60\% of energy derived from fat) for $7 \mathrm{~d}$ on the contribution of different fat compartments to total fat oxidation. In seven healthy lean subjects, we measured total fat oxidation using a respiration chamber and determined plasma fatty acid oxidation using infusion of ${ }^{13} \mathrm{C}$-labelled palmitate. Total fat oxidation increased slowly on the highfat diet and this increase in fat oxidation was accounted for by an increase in non-plasma fatty acid oxidation (Schrauwen et al. 2000). This suggests that the oxidation of VLDL-triacylglycerol or intramuscular triacylglycerol is increased on a high-fat diet. It has previously been shown that after consumption of a high-fat diet intramuscular triacylglycerol concentration was elevated in healthy subjects (Kiens et al. 1987; Starling et al. 1997) and it can be suggested that an increased intramuscular triacylglycerol concentration allows an increased intramuscular triacylglycerol oxidation. After switching from a low-fat to a high-fat diet, intramuscular triacylglycerol concentration will gradually increase and this might result in the gradual increase in fat oxidation. On the other hand, lipoprotein lipase activity, the enzyme responsible for releasing fatty acids from the lipoproteins (VLDL) is increased after consumption of a high-fat diet (Kiens et al. 1987) and a relationship between lipoprotein lipase activity and wholebody fat oxidation has been shown (Ferraro et al. 1993). The increased lipoprotein lipase activity on a high-fat diet might facilitate the uptake and storage of VLDL-triacylglycerol by the muscle, explaining the increase in intramuscular triacylglycerol concentration on a high-fat diet. However, part of the fatty acids released from VLDLtriacylglycerol might also be directly oxidized in the muscle, especially in the post-absorptive state. More studies are required to establish the role of either intramuscular or VLDL-triacylglycerol oxidation in the adaptation of fat oxidation to a high-fat intake. A role for intramuscular triacylglycerol concentration and oxidation in the adaptation to a high-fat diet is interesting because a relationship between intramuscular triacylglycerol concentration and insulin sensitivity has been shown (Philips et al. 1996; Pan et al. 1997). Thus, high intramuscular triacylglycerol concentrations are correlated with a low insulin sensitivity. These findings might provide the link between high-fat diets, obesity and insulin resistance. However, more information on the role of intramuscular triacylglycerols in the development of obesity and insulin resistance is required.

\section{Genetic determinants of obesity}

Apart from environmental factors, obesity is also determined by genetic factors. Estimates of the heritability of body composition suggest that $40-70 \%$ of the variation in body composition is genetic (Stunkard et al. 1990). In recent years, the discovery of two previously unknown genes, the $a b$ gene, encoding for the adiposity hormone leptin, and the uncoupling protein-2 and uncoupling protein-3 genes, encoding for uncoupling proteins, renewed the interest in genetic determinants of obesity.

In 1994, the $o b$ gene, encoding for the ob protein (leptin) was discovered by Zhang et al. (1994). In a strain of extremely obese mice, $(o b / o b)$, leptin is absent due to a mutation in the $o b$ gene, and administration of leptin to these mice led to an increase in food intake and a decrease in body weight. Another strain of extremely obese mice $(d b / d b)$ have a mutation in the gene encoding for the leptin receptor and therefore leptin can not exert its effects. In human subjects, in a few families only, mutations in the leptin (receptor) gene have been found which resulted in extreme obesity (Montague et al. 1997; Clément et al. 1998; Strobel et al. 1998). Therefore, research has focused mainly on the normal regulation of leptin concentrations. Increasing evidence suggests that leptin exerts its effect 
through the hypothalamus. The synthesis of hypothalamic neuropeptide Y, a potent stimulator of food intake, is inhibited by leptin (Stephens et al. 1995). Evidence is also accumulating for an effect of leptin on lipid metabolism. In cell cultures, leptin directly reduces intracellular lipid concentrations by inhibiting fatty acid and triacylglycerol synthesis and increases lipid oxidation (Shimabukuro et al. 1997). Recently Wang et al. (1998) showed that hyperlipidaemia and hyperglycaemia resulted in increased leptin expression in white adipose tissue and, interestingly, also in skeletal muscle. This finding might unveil an important link between increased nutrient availability and leptin expression. However, most of the variability in leptin expression is explained by the size of the adipose tissue stores. In obese human subjects, leptin levels are elevated in close relation to the body fat mass, eliminating a causal role for (low) leptin levels on obesity, although in Pima Indians low leptin levels predispose to future weight gain (Ravussin et al. 1997). Leptin might play a role in the interaction between genetic and environmental factors since it was shown that consumption of a high-fat diet led to an increase in leptin levels in rats (Frederich et al. 1995; Masuzaki et al. 1995) and this effect could possibly explain the variability in body composition between individuals on similar diets. However, the increase in leptin levels was best explained by the increase in fat mass. In accordance, isoenergetic low- and high-fat diets had no effect on leptin concentrations, but leptin levels were correlated with body fat percentage, as was described earlier (Schrauwen et al. 1997d). This suggests that leptin does not play a role in the prevention of diet-induced obesity and can not explain why some subjects become obese on high-fat diets whereas others maintain normal weight.

In brown adipose tissue an uncoupling protein, uncoupling protein-1, is responsible for the thermogenic effect of this tissue (Nicholls et al. 1978). Uncoupling proteins are able to uncouple $\mathrm{O}_{2}$ consumption from ATP production, thereby dissipating energy as heat. In rodents, brown adipose tissue is involved in the cold-induced and dietinduced thermogenesis. When overfed on a high-fat diet therefore, rodents can maintain energy balance by increasing brown adipose tissue activity (equal to uncoupling protein activity) and thus expending a large part of the excess energy. However, brown adipose tissue is limited in adult man, and therefore the role of uncoupling proteins in human obesity has long been controversial (Lean et al. 1986). In 1997, two novel uncoupling proteins, uncoupling protein-2 (Fleury et al. 1997; Gimeno et al. 1997) and uncoupling protein-3 (Boss et al. 1997), which are widely expressed in human tissues, were cloned. Recently, we found that in Pima Indians, who have a predisposition to obesity, the mRNA levels of uncoupling protein-3 were positively correlated with sleeping metabolic rate. This suggests that low uncoupling protein-3 levels, and thus low heat production, would result in a low sleeping metabolic rate (Schrauwen et al. 1999). Interestingly, high-fat feeding upregulates the expression of uncoupling protein-2 (Fleury et al. 1997) and uncoupling protein-3 (Matsuda et al. 1997) in rats, due to an effect of free fatty acids on uncoupling protein-2 and uncoupling protein-3 expression (Weigle et al. 1998). It was observed in obesity-resistant mice, which do not become obese when fed a high-fat diet, that uncoupling protein-2 was upregulated by high-fat feeding whereas in obesity-susceptible mice high-fat feeding had no effect on uncoupling protein-2. Therefore, uncoupling proteins might play a role in diet-induced obesity, and high expression of uncoupling proteins would be beneficial in preventing obesity.

These results indicate that genetic factors might be important in the development of obesity, but even in subjects with a genetic predisposition to obesity, environmental factors are the most important determinants of body weight and/or composition. This interaction between environmental and genetic determinants was shown by Ravussin et al. (1994), who studied two populations with a similar genetic background (Pima Indians) living in different environments. The Pima Indians who live in Mexico have a traditional lifestyle, with a low-fat diet and high levels of physical activity. The mean BMI of these Mexican Pima Indians is $7-10 \mathrm{~kg} / \mathrm{m}^{2}$ below the mean BMI of the Pima Indians living in the USA, who have a westernized lifestyle. Therefore, a high-fat diet, in combination with low physical activity, seems to be the most important determinant of the increased prevalence of obesity in our westernized society.

\section{Conclusion}

In the present review evidence has been presented that high-fat diets play an important role in the increased prevalence of obesity. Due to their high energy density, high-fat diets will stimulate voluntary energy intake. This increased intake of dietary fat will not stimulate fat oxidation but the excess fat intake will be stored in the adipose tissue, so there is a close correlation between energy balance and fat balance. Even when isoenergetic high- and low-fat diets are compared, high-fat diets will lead to a positive fat balance in the short term due to the lack of adjustment of fat oxidation to fat intake. In the long term, cumulative positive fat balances could lead to weight gain. The lack of adjustment of fat oxidation to a high-fat intake can be counteracted by performing physical activity, leading to lowering of the glycogen stores.

\section{References}

Abbott WG, Howard BV, Ruotolo G \& Ravussin E (1990) Energy expenditure in humans: effects of dietary fat and carbohydrate. American Journal of Physiology 258, E347-E351.

Astrup A, Buemann B, Christensen NJ \& Toubro S (1994) Failure to increase lipid oxidation in response to increasing dietary fat content in formerly obese women. American Journal of Physiology 266, E592-E599.

Bennett C, Reed GW, Peters JC, Abumrad NN, Sun M \& Hill JO (1992) Short-term effects of dietary-fat ingestion on energy expenditure and nutrient balance. American Journal of Clinical Nutrition 55, 1071-1077.

Blaak EE, Baak MAv, Kemerink GJ, Pakbiers MTW, Heidendal GAK \& Saris WHM (1994) B-Adrenergic stimulation of energy expenditure and forearm skeletal muscle metabolism in lean and obese men. American Journal of Physiology 267, E306E315. 
Blundell JE, Burley VJ, Cotton JR \& Lawton CL (1993) Dietary fat and the control of energy intake: evaluating the effects of fat on meal size and postmeal satiety. American Journal of Clinical Nutrition 57, 772S-777S.

Blundell JE \& Macdiarmid JI (1997) Fat as a risk factor for overconsumption: satiation, satiety, and patterns of eating. Journal of the American Dietetic Association 97, S63-S69.

Boss O, Samec S, Paoloni-Giacobino A, Rossier C, Dulloo A, Seydoux J, Muzzin P \& Giacobino J-P (1997) Uncoupling protein-3: a new member of the mitochondrial carrier family with tissue-specific expression. FEBS Letters 408, 39-42.

Boyle CA, Dobson AJ, Egger G \& Magnus P (1994) Can the increasing weight of Australians be explained by the decreasing prevalence of cigarette smoking? International Journal of Obesity and Related Metabolic Disorders 18, 55-60.

Clément K, Vaisse C, Lahlou N, Cabrol S, Pelloux V, Cassuto D, Gourmelen M, Dina C, Chambaz J, Lacorte JM, Basdevant A, Bougneres P, Lebouc Y, Froguel P \& Guy-Grand B (1998) A mutation in the human leptin receptor gene causes obesity and pituitary dysfunction. Nature 392, 398-401.

Dallosso HM \& James WP (1984) Whole-body calorimetry studies in adult men. 1. The effect of fat over-feeding on $24 \mathrm{~h}$ energy expenditure. British Journal of Nutrition 52, 49-64.

Davis JR, Tagliaferro AR, Kertzer R, Gerardo T, Nichols J \& Wheeler J (1983) Variations in dietary-induced thermogenesis and body fatness with aerobic capacity. European Journal of Applied Physiology 50, 319-329.

Eck LH, Hackett-Renner C \& Klesges LM (1992) Impact of diabetic status, dietary intake, physical activity, and smoking status on body mass index in NHANES II. American Journal of Clinical Nutrition 56, 329-333.

Ferraro RT, Eckel RH, Larson DE, Fontvieille A, Rising R, Jensen DR \& Ravussin E (1993) Relationship between skeletal muscle lipoprotein lipase activity and 24-hour macronutrient oxidation. Journal of Clinical Investigation 92, 441-445.

Flatt JP (1987a) Dietary fat, carbohydrate balance, and weight maintenance: effects of exercise. American Journal of Clinical Nutrition 45, 296-306.

Flatt JP (1987b) The difference in the storage capacities for carbohydrate and for fat, and its implications in the regulation of body weight. Annals of the New York Academy of Science 499, 104-123.

Flatt JP (1988) Importance of nutrient balance in body weight regulation. Diabetes Metabolism Reviews 4, 571-581.

Flatt JP, Ravussin E, Acheson KJ \& Jequier E (1985) Effects of dietary fat on postprandial substrate oxidation and on carbohydrate and fat balances. Journal of Clinical Investigation 76, 1019-1024.

Flegal KM, Carroll MD, Kuczmarski RJ \& Johnson CL (1998) Overweight and obesity in the United States: prevalence and trends 1960-1994. International Journal of Obesity 22, 39-47.

Fleury C, Neverova M, Collins S, Raimbault S, Champigny O, Levi-Meyrueis C, Bouillaud F, Seldin MF, Surwit RS, Ricquier D \& Warden CH (1997) Uncoupling protein-2: a novel gene linked to obesity and hyperinsulinemia. Nature Genetics $\mathbf{1 5}$, 269-273.

Frederich RC, Hamann A, Anderson S, Löllmann B, Lowell BB \& Flier JS (1995) Leptin levels reflect body lipid content in mice: evidence for diet-induced resistance to leptin action. Nature Medicine 1, 1311-1314.

Gimeno RE, Dembski M, Weng X, Deng N, Shyjan AW, Gimeno CJ, Iris F, Ellis SJ, Woolf EA \& Tartaglia LA (1997) Cloning and characterization of an uncoupling protein homolog: a potential molecular mediator of human thermogenesis. Diabetes 46, 900-906.

Gore CJ \& Whither RT (1990) The effect of exercise intensity and duration on the oxygen deficit and excess post-exercise oxygen consumption. European Journal of Applied Physiology 60, $169-174$

Hill JO, Peters JC, Reed GW, Schlundt DG, Sharp T \& Greene HL (1991) Nutrient balance in humans: effects of diet composition. American Journal of Clinical Nutrition 54, 10-17.

Horton TJ, Drougas H, Brachey A, Reed GW, Peters JC \& Hill JO (1995) Fat and carbohydrate overfeeding in humans: Different effects on energy storage. American Journal of Clinical Nutrition 62, 19-29.

Hurni M, Burnand B, Pittet P \& Jequier E (1982) Metabolic effects of a mixed and a high-carbohydrate low-fat diet in man, measured over $24 \mathrm{~h}$ in a respiration chamber. British Journal of Nutrition 47, 33-43.

Katan MB, Grundy SM \& Willett WC (1997) Beyond low-fat diets. New England Journal of Medicine 337, 563-566.

Keil U \& Kuulasmaa K (1989) WHO MONICA project: risk factors. International Journal of Epidemiology 18, S46-S55.

Kiens B, Essen-Gustavsson B, Gad P \& Lithell H (1987) Lipoprotein lipase activity and intramuscular triglyceride stores after long-term high-fat and high-carbohydrate diets in physically trained men. Clinical Physiology 7, 1-9.

Klesges RC, Klesges LM, Haddock CK \& Eck LH (1992) A longitudinal analysis of the impact of dietary intake and physical activity on weight change in adults. American Journal of Clinical Nutrition 55, 818-822.

Kuczmarski RJ, Flegal KM, Campbell SM \& Johnson CL (1994) Increasing prevalence of overweight among US adults. The National Health and Nutrition Examination Surveys, 1960 to 1991. Journal of the American Medical Association 272, 205211.

Lean ME \& James WP (1988) Metabolic effects of isoenergetic nutrient exchange over 24 hours in relation to obesity in women. International Journal of Obesity 12, 15-27.

Lean ME, James WP, Jennings G \& Trayhurn P (1986) Brown adipose tissue uncoupling protein content in human infants, children and adults. Clinical Science 71, 291-297.

Lissner L \& Heitmann BL (1995) Dietary fat and obesity: evidence from epidemiology. European Journal of Clinical Nutrition 49, 79-90.

Lissner L, Levitsky DA, Strupp BJ, Kalkwarf HJ \& Roe DA (1987) Dietary fat and the regulation of energy intake in human subjects. American Journal of Clinical Nutrition 46, 886-892.

McNeill G, Bruce AC, Ralph A \& James WP (1988) Interindividual differences in fasting nutrient oxidation and the influence of diet composition. International Journal of Obesity 12, 455-463.

Masuzaki H, Ogawa Y, Hosoda K, Kawada T, Fushiki T \& Nakao K (1995) Augmented expression of the obese gene in the adipose tissue from rats fed high-fat diet. Biochemical and Biophysical Research Communications 216, 355-358.

Matsuda J, Hosoda K, Itoh H, Son C, Doi K, Tanaka T, Fukunaga Y, Inoue G, Nishimura H, Yoshimasa Y, Yamori Y \& Nakao K (1997) Cloning of rat uncoupling protein-3 and uncoupling protein-2 cDNAs: their gene expression in rats fed high-fat diet. FEBS Letters 418, 200-204.

Millar WJ \& Stephens T (1993) Social status and health risks in Canadian adults: 1985 and 1991. Health Reports 5, 143-156.

Miller WC, Lindeman AK, Wallace J \& Niederpruem M (1990) Diet composition, energy intake, and exercise in relation to body fat in men and women. American Journal of Clinical Nutrition 52, 426-430.

Montague CT, Farooqi IS, Whitehead JP, Soos MA, Rau H, Wareham NJ, Sewter CP, Digby JE, Mohammed SN, Hurst JA, Cheetham CH, Earley AR, Barnett AH, Prins JB \& O'Rahilly S (1997) Congenital leptin deficiency is associated with severe early-onset obesity in humans. Nature 387, 903-908.

Monteiro CA, Mondini L, de Souza AL \& Popkin BM (1995) The 
nutrition transition in Brazil. European Journal of Clinical Nutrition 49, 105-113.

Nicholls D, Bernson V \& Heaton G (1978) The identification of the component in the inner membrane responsible for regulating energy dissipation. In Effectors of Thermogenesis, pp. 89-93. Basel: Birkhauser Verlag.

Pan DA, Lillioja S, Kriketos AD, Milner MR, Baur LA, Bogardus C, Jenkins AB \& Storlien LH (1997) Skeletal muscle triglyceride levels are inversely related to insulin action. Diabetes 46, 983-989.

Phelain JF, Reinke E, Harris MA \& Melby CL (1997) Postexercise energy expenditure and substrate oxidation in young women resulting from exercise bouts of different intensity. Journal of the American College of Nutrition 16, 140-146.

Philips DIW, Caddy S, Ilic V, Fielding BA, Frayn KN, Borthwick AC \& Taylor R (1996) Intramuscular triglyceride and muscle insulin sensitivity: evidence for a relationship in nondiabetic subjects. Metabolism 45, 947-950.

Poehlman ET, Melby CL, Bradylak SF \& Calles J (1988) Resting metabolic rate and postprandial thermogenesis in highly trained and untrained males. American Journal of Clinical Nutrition 47, 793-798.

Poppitt SD (1995) Energy density of diets and obesity. International Journal of Obesity 19, S20-S26.

Prewitt TE, Schmeisser D, Bowen PE, Aye P, Dolecek TA, Langenberg P, Cole T \& Brace L (1991) Changes in body weight, body composition, and energy intake in women fed high- and low-fat diets. American Journal of Clinical Nutrition 54, 304-310.

Ravussin E, Lillioja S, Anderson TE, Christin L \& Bogardus C (1986) Determinants of 24-hour energy expenditure in man. Methods and results using a respiratory chamber. Journal of Clinical Investigation 78, 1568-1578.

Ravussin E, Pratley RE, Maffei M, Wang H, Friedman JM, Bennett PH \& Bogardus C (1997) Relatively low plasma leptin concentrations precede weight gain in Pima Indians. Nature Medicine 3, 238-240.

Ravussin E, Valencia ME, Esparza J, Bennett PH \& Schulz LO (1994) Effects of a traditional lifestyle on obesity in Pima Indians. Diabetes Care 17, 1067-1074.

Romieu I, Willett WC, Stampfer MJ, Colditz GA, Sampson L, Rosner B, Hennekens CH \& Speizer FE (1988) Energy intake and other determinants of relative weight. American Journal of Clinical Nutrition 47, 406-412.

Romijn JA, Coyle EF, Sidossis LS, Gastaldelli A, Horowitz JF, Endert E \& Wolfe RR (1993) Regulation of endogenous fat and carbohydrate metabolism in relation to exercise intensity and duration. American Journal of Physiology 265, E380-E391.

Saltzman E, Dallal GE \& Roberts SB (1997) Effect of high-fat and low-fat diets on voluntary energy intake and substrate oxidation: studies in identical twins consuming diets matched for energy density, fiber, and palatability. American Journal of Clinical Nutrition 66, 1332-1339.

Saris WHM (1996) Physical activity and body weight regulation. In Regulation of Body Weight: Biological and Behavioral Mechanisms, pp. 135-147, New York, NY: John Wiley \& Sons Ltd.

Schrauwen P, Marken Lichtenbelt WDv, Saris WHM \& Westerterp KR (1997a) Changes in fat oxidation in response to a highfat diet. American Journal of Clinical Nutrition 66, 276-282.

Schrauwen P, Marken Lichtenbelt WDv, Saris WHM \& Westerterp KR (1997b) Role of glycogen-lowering exercise in the change of fat oxidation in response to a high-fat diet. American Journal of Physiology 273, E623-E629.

Schrauwen P, Marken Lichtenbelt WDv, Saris WHM \& Westerterp KR (1998) Fat balance in obese subjects: Role of glycogen stores. American Journal of Physiology 274, E1027-E1033.
Schrauwen P, Marken Lichtenbelt WDv \& Westerterp KR (1997c) Energy balance in a respiration chamber: individual adjustment of energy intake to energy expenditure. International Journal of Obesity 21, 769-774.

Schrauwen P, Marken Lichtenbelt WDv, Westerterp KR \& Saris WHM (1997d) The effect of diet composition on leptin concentration in lean subjects. Metabolism 46, 420-424.

Schrauwen P, Wagenmaker AJM, Marken Lichtenbelt WDv, Saris WHM \& Westerterp KR (2000) The increase in fat oxidation on a high-fat diet is accompanied by an increase in triglyceridederived fatty acid oxidation. Diabetes 49, 640-646.

Schrauwen P, Xia J, Bogardus C, Pratley R \& Ravussin E (1999) Skeletal muscle UCP3 expression is a determinant of energy expenditure in Pima Indians. Diabetes 48, 146-149.

Schulz LO, Nyomba BL, Alger S, Anderson TE \& Ravussin E (1991) Effect of endurance training on sedentary energy expenditure measured in a respiratory chamber. American Journal of Physiology 260, E257-E261.

Schulz LO \& Schoeller DA (1994) A compilation of total daily energy expenditures and body weights in healthy adults. American Journal of Clinical Nutrition 60, 676-681.

Schutz Y, Flatt JP \& Jequier E (1989) Failure of dietary fat intake to promote fat oxidation: a factor favoring the development of obesity. American Journal of Clinical Nutrition 50, 307-314.

Sedlock DA (1991) Effect of exercise intensity on postexercise energy expenditure in women. British Journal of Sports Medicine 25, 38-40.

Sedlock DA, Fissinger JA \& Melby CL (1989) Effect of exercise intensity and duration on postexercise energy expenditure. Medicine and Science in Sports Exercise 21, 662-666.

Seidell JC (1995) Obesity in Europe: scaling an epidemic. International Journal of Obesity and Related Metabolic Disorders 19, Suppl. 3, S1-S4.

Seidell JC \& Rissanen AM (1997) Time trends in the worldwide prevalence of obesity. In Handbook of Obesity, pp. 79-91, New York, NY: Marcel Dekker Inc.

Shimabukuro M, Koyama K, Chen G, Wang MM, Trieu F, Lee Y, Newgard CB \& Unger RH (1997) Direct antidiabetic effect of leptin through triglyceride depletion of tissues. Proceedings of the National Academy of Sciences, USA 94, 4637-4641.

Smith J \& Naughton L (1993) The effects of intensity of exercise on excess postexercise oxygen consumption and energy expenditure in moderately trained men and women. European Journal of Applied Physiology 67, 420-425.

Sonne-Holm S \& Sorensen TI (1977) Post-war course of the prevalence of extreme overweight among Danish young men. Journal of Chronic Diseases 30, 351-358.

Starling RD, Trappe TA, Parcell AC, Kerr CG, Fink WJ \& Costill DL (1997) Effects of diet on muscle triglyceride and endurance performance. Journal of Applied Physiology 82, 1185-1189.

Stephens TW, Basinski M, Bristow PK, Bue-Valleskey JM, Burgett SG, Craft L, Hale J, Hoffmann J, Hsiung HM, Kriauciunas A, MacKellar W, Rosteck PR, Schoner B, Smith D, Tinsley FC, Zhang X-Y \& Heiman M (1995) The role of neuropeptide $\mathrm{Y}$ in the antiobesity action of the obese gene product. Nature 377, 530-532.

Strobel A, Issad T, Camoin L, Ozata M \& Strosberg AD (1998) A leptin missense mutation associated with hypogonadism and morbid obesity. Nature Genetics 18, 213-215.

Stunkard AJ, Harris JR, Pedersen NL \& McClearn GE (1990) The body-mass index of twins who have been reared apart. New England Journal of Medicine 322, 1483-1487.

Stunkard AJ, Sorensen TIA, Hanis C, Teasdale TW, Chakraborty R, Schull WJ \& Schulsinger F (1986) An adoption study of human obesity. New England Journal of Medicine 314, 193198.

Thomas CD, Peters JC, Reed GW, Abumrad NN, Sun M \& Hill 
JO (1992) Nutrient balance and energy expenditure during ad libitum feeding of high-fat and high-carbohydrate diets in humans. American Journal of Clinical Nutrition 55, 934-942.

Tremblay A, Fontaine E, Poehlman ET, Mitchell D, Perron L \& Bouchard C (1986) The effect of exercise-training on resting metabolic rate in lean and obese moderately obese individuals. International Journal of Obesity 10, 511-517.

Tremblay A, Simoneau J-A \& Bouchard C (1994) Impact of exercise intensity on body fatness and skeletal muscle metabolism. Metabolism 43, 814-818.

Treuth MS, Hunter GR \& Williams M (1996) Effects of exercise intensity on 24 h-energy expenditure and substrate oxidation. Medicine and Science in Sports Exercise 28, 1138-1144.

Verboeket-van de Venne WPHG, Westerterp KR, HermansLimpens TJFMB, Graaf Cd, Hof Kvh \& Weststrate JA (1996) Long-term effects of consumption of full-fat or reduced-fat products in healthy non-obese volunteers: assessment of energy expenditure and substrate oxidation. Metabolism 45, 10041010.

Verboeket-van de Venne WPHG, Westerterp KR \& ten Hoor F (1994) Substrate utilization in man: effects of dietary fat and carbohydrate. Metabolism 43, 152-156.

Wang J, Rong L, Hawkins M, Barzilai N \& Rossetti L (1998) A nutrient-sensing pathway regulates leptin gene expression in muscle and fat. Nature 393, 684-688.

Weigle DS, Selfridge LE, Schwartz MW, Seeley RJ, Cummings DE, Havel PJ, Kuijper JL \& BertrandelRio H (1998) Elevated free fatty acids induce uncoupling protein 3 expression in muscle. A potential explanation for the effect of fasting. Diabetes 47, 298-302.
Westerterp KR (1999) Obesity and physical activity. International Journal of Obesity 23, 59-64.

Westerterp KR \& Goran MI (1997) Relationship between physical activity related energy expenditure and body composition: a gender difference. International Journal of Obesity 21, 184188.

Westerterp KR, Meijer GAL, Schoffelen P \& Janssen E (1994) Body mass, body composition and sleeping metabolic rate before, during and after endurance training. European Journal of Applied Physiology 69, 203-208.

Westerterp KR, Verboeket-van de Venne WPHG \& Bouten C (1996a) Energy expenditure and physical activity in subjects consuming full- or reduced-fat products as part of their normal diet. British Journal of Nutrition 76, 785-795.

Westerterp KR, Verboeket-van de Venne WPHG, WesterterpPlantenga MS, Velthuis-te Wierik EJM, Graaf Cd \& Weststrate JA (1996b) Dietary fat and body fat: an intervention study. International Journal of Obesity 20, 1022-1026.

Westerterp-Plantenga MS, Pasman WJ \& Wijckmans-Duijsens NEG (1996) Energy intake adaptation of food intake to extreme energy densities of food by obese and non-obese women. European Journal of Clinical Nutrition 50, 401-407.

Westerterp-Plantenga MS, Verwegen CRT, Ijedema MJW, Wijckmans NEG \& Saris WHM (1997) Acute effects of exercise or sauna on appetite in obese and nonobese men. Physiology \& Behavior 62, 1345-1354.

Zhang Y, Proenca R, Maffei M, Barone M, Leopold L \& Friedman JM (1994) Positional cloning of the mouse obese gene and its human homologue. Nature 372, 425-432. 